\title{
PENGETAHUAN, PENGELUARAN DAN KONSUMSI SAYUR-BUAH PADA MAHASISWA GIZI DAN NON GIZI POLTEKKES KEMENKES TASIKMALAYA
}

\author{
Agus Bachtiar ${ }^{1}$, Sumarto ${ }^{2}$, Ima Karimah ${ }^{3}$, Irma Nuraeni ${ }^{4}$ \\ ${ }^{1,2,3,4}$ Dosen Jurusan Gizi Politeknik Kesehatan Kemenkes Tasikmalaya
}

\begin{abstract}
ABSTRAK
Indonesia negara dengan keanekaragaman jenis buah dan sayuran tropis, namun jumlah yang dikonsumsi per kapita lebih sedikit dibandingkan dengan di wilayah iklim sedang (Williams et al., 1993). Laporan Riskesdas 2007 dan 2013 menunjukkan masih tingginya proporsi rerata nasional perilaku konsumsi kurang sayur dan atau buah pada penduduk umur> 10 tahun, yaitu sebesar 93,5\% dan 93,6\% (Depkes, 2008: Kemenkes, 2013). Tujuan penelitian ini untuk mengetahui gambaran pengetahuan, pengeluaran dan konsumsi sayurbuah pada mahasiswaGizi dan non-Gizi Poltekkes Kemenkes Tasikmalaya. Metode penelitian adalah deskriptif-analitik. Subjek penelitian sebanyak 41 orang mahasiswa Gizi dan 35 orang mahasiswa non-Gizi Poltekkes Kemenkes Tasikmalaya pada bulan Desember 2015. Teknik pengambilan sampel purposive sampling. Pengumpulan data dilakukan dengan metode wawancara dan pengisian kuesioner. Kemudian data diolah dan dianalisis menggunakan program komputer. Hasil penelitian menunjukkan bahwa sebagian besar pengetahuan sayur buah mahasiswa Gizi dan non-Gizi tergolong kategori sedang. Pengetahuan sayur dan buah mahasiswa Gizi lebih baik daripada non-Gizi. Rerata pengeluaran untuk konsumsi sayurdanbuahpada mahasiswa Gizi lebih rendah daripada non-Gizi. Rerata jumlah total konsumsi sayur dan buah lebih tinggi pada mahasiswa Gizi daripada non-Gizi, namun beberapa masih belum sesuai anjuran dari segi jumlah maupun frekuensinya.
\end{abstract}

Kata kunci : Pengetahuan, Pengeluaran, Konsumsi Sayur dan Buah, Mahasiswa

\begin{abstract}
Indonesiais a country witha diversity oftropical fruit and vegetables, but theamount of consumingpercapita islessthan in thesubtropical climate countries (Williams et al., 1993).Riskesdas data in 2007and2013reported that was high proportion ofnational averagelack behaviour consumption offruit and vegetablesin more than10years of aged population, 93.5\% and93.6\% (Depkes, 2007: Kemenkes, 2013). The aims of this study was to overview knowledge, expenditure, and fruit-vegetables consumption in department of nutrition and non-nutrition student of Poltekkes Kemenkes Tasikmalaya. The Method was descriptive-analytical. The subjects was 41 students from department of nutrition and nonnutrition of Poltekkes Kemenkes Tasikmalaya in December 2015. Technical sampling was purposive sampling. Data collected byinterview andquestionnaire. Then the datawas processedandanalyzed usinga computerprogram. Result showed that the majority of nutrition and non-nutrition student was moderate knowledge. However, when it compared, knowledge of nutrition students better than non nutrition students. The average of expenditure for fruit and vegetable consumption in nutrition student lower than non nutrition student. The average of total fruit and vegetables consumption was higher in nutrition students than non-nutritionstudent, but some of them were not as recommended in terms of quantity and frequency.
\end{abstract}

Keyword : Knowledge, Expenditure, Fruit-Vegetables Consumption, Student 


\section{PENDAHULUAN}

Saat ini Indonesia mengalami beban ganda masalah gizi, yaitu masalah gizi kurang dan lebih. Laporan Riskesdas menunjukkan semakin meningkatnya prevalensi gizi lebih pada tahun 2013 dibandingkan dengan tahun 2007. Pada tahun 2013, prevalensi obesitas perempuan dewasa (>18 tahun) $32,9 \%$, naik $18,1 \%$ dari tahun $2007(13,9 \%)$ dan 17,5\% dari tahun 2010 (15,5\%) (Kemenkes, 2013). Solusi terhadap masalah ini adalah pengaturan pola makan dengan berprinsip gizi seimbang akan dapat memproteksi diri dari penyakit tidak menular. Konsumsi sayuran dan buahbuahan yang cukup merupakan salah satu indikator sederhana gizi seimbang yang tertuang dalam pesan gizi seimbang tahun 2014 (Kemenkes RI, 2014).

Indonesia memiliki kekayaan biodiversitas sayuran dan buah-buahan. Setiap daerah memiliki keunggulan dan kekhasan akan sayuran dan buah-buahan lokal yang dihasilkannya. Terlepas dari keanekaragaman jenis buah dan sayuran tropis dan ketersediaannya dari hasil produksi maupun impor, namun jumlah yang dikonsumsi per kapita lebih sedikit dibandingkan dengan di wilayah iklim sedang terutama di negara-negara maju (Williams et al., 1993). Hal ini didukung data laporan Riskesdas tahun 2007 menunjukkan masih tingginya proporsi rerata nasional perilaku konsumsi kurang sayur dan atau buah pada penduduk umur $>10$ tahun, yaitu sebesar 93,5 \%, dan hasilRiskesdas 2013, yaitu sebesar 93,6\% (Depkes, 2008 : Kemenkes, 2013). Berdasarkan Studi Diet Total Survei

\section{METODE PENELITIAN}

Jenis penelitian ini merupakan deskriptifanalitik yang dilaksanakan pada bulan Desember 2015, di lokasi Poltekkes Kemenkes Tasikmalaya Wilayah Kampus Cilolohan Tasikmalaya. Populasi penelitian ini adalah Mahasiswa Poltekkes Kemenkes Tasikmalaya, sedangkan subjek penelitian adalah 41 Mahasiswa Tingkat III Prodi DIII Gizi dan 35 Prodi DIII PIKES (Perekam dan
Konsumsi Makanan Individu Indonesia tahun 2014 menunjukkan bahwa rerata konsumsi sayur dan olahannya penduduk Indonesia sebesar 57,1 gram per orang per hari, sedangkan berdasarkan umur 19-55 tahun rerata konsumsi sayur dan olahannya sebesar 64,5 gram per orang per hari. Rerata konsumsi buah-buahan dan olahannya untuk penduduk Indonesia terlihat masih rendah yaitu 33,5 gram per orang per hari (Badan Litbangkes, 2014). Padahal Badan Kesehatan Dunia (WHO) secara umum menganjurkan konsumsi sayuran dan buah-buahan untuk hidup sehat sejumlah 400 gram perorang perhari, yang terdiri atas 250 gram dan 150 gram buah. Bagi orang Indonesia dianjurkan konsumsi sayuran dan buah-buahan 400-600 gram perorang perhari bagi remaja dan orang dewasa (Kemenkes RI, 2014).

Peningkatan pendapatan merupakan salah satu faktor yang berpeluang untuk dapat membeli pangan dengan kualitas maupun kuantitas yang baik. Berdasarkan olah data Susenas 2013 rata-rata pengeluaran rumah tangga per kapita sebulan di daerah perkotaan dan perdesaan menurut konsumsi sayur buah tahun 20132014, untuk pengeluaran konsumsi buahbuahan mengalami peningkatan di tahun 2014 sebesar Rp. 19.243/kapita/bulan, jika dibandingkan dengan tahun 2013 sebesar Rp. 16.379/kapita/bulan (BPS, 2014). Tujuan penelitian ini adalah untuk mengetahui gambaran pengetahuan, pengeluran dan konsumsi sayur-buah pada mahasiswagizi dan non gizi Poltekkes Kemenkes Tasikmalaya.

Informasi Kesehatan) Poltekkes Kemenkes Tasikmalaya, sehingga jumlah total sampel 76 orang dengan teknik sampling yang digunakan adalah purpossive sampling yang memenuhi kriteria inklusi, yaitu mahasiswatingkattiga semester lima dan bersediamengikutipenelitian. Kriteria eksklusi, yaitu sakit dan tidakhadir pada saat penelitian. 
Variabel penelitian ini adalah pengetahuan, pengeluaran dan konsumsi sayur buah. Pengetahuan adalah kemampuan mahasiswa dalam menjawab pertanyaan kuesioner tentang gizi dan sayur buah dengan benar dan dinyatakan dalam skor. Pengeluaran adalah jumlah pengeluaran untuk sayur dan buah yang berasal dari pembelian, produksi sendiri maupun pemberian selama 1 (satu) bulan terakhir yang dinyatakan dalam rupiah. Konsumsi Sayur Buah terdiri dari frekuensi dan jumlah. Frekuensi konsumsi buah atau sayur adalah derajat keseringan mengkonsumsi buah dalam hari, minggu dan bulan selama 1 bulan terakhir, yang kemudian dikategorikan menjadi $<1$ kali/hari dan $\geq 1$ kali/hari. Jumlah konsumsi buah dan sayur adalah jumlah buah dan sayur yang dikonsumsi baik dalam keadaan mentah atau olahannya, bentuk padat maupun cair. Jumlah buah dan sayur setiap kali konsumsi dari ukuran rumah tangga (URT), kemudian dikonversikedalamukuranberat (g) per hari selamasatubulanterakhirdan

\section{HASIL DAN PEMBAHASAN}

\section{A. Identitas Responden}

dikategorikanmenjadijumlah konsumsi buah dan sayur $<400 \mathrm{~g} / \mathrm{hari}$ dan $\geq 400 \mathrm{~g} / \mathrm{hari}$. Penggunaan cut off $400 \mathrm{gr} / \mathrm{hari}$ didasari rekomendasi Pedoman Gizi Seimbang tahun 2014. Data primer diperoleh dari mencatat langsung melalui wawancara dengan responden dan pengisian kuesioner oleh responden. Data Primer meliputi identitas responden, pengetahuan tentang sayur dan buah, pengeluaran biaya untuk konsumsi sayur buah serta jumlah, jenis dan frekuensi konsumsi sayur buah. Data Sekunder pada penelitian ini mengenai gambaran umum wilayah penelitian serta daftar nama mahasiswa. Instrumen penelitian adalah kuesioner yang berisi pertanyaan tertutup maupun terbuka. Instrumen yang digunakan adalah modifikasi SQFFQ (Semi Quantitative Food Frequency), kuesioner pengetahuan buah dan sayur, serta kuesioner pengeluaran. Data diolah dan dianalisis menggunakan statistik sederhana berupa deskripsi rerata, standar deviasi serta distribusi frekuensi masing-masing variabel.

Tabel 1. Distribusi Frekuensi Karakteristik Responden

\begin{tabular}{|c|c|c|}
\hline $\begin{array}{llllll} & a & r & i & a & b\end{array}$ & $\mathrm{n}$ & $\%$ \\
\hline \multicolumn{3}{|l|}{ Jurusan/ Prodi } \\
\hline DIII Gizi & 41 & 53.95 \\
\hline DIII PIKES (Non gizi) & 35 & 46.05 \\
\hline \multicolumn{3}{|l|}{ Jenis Kelamin } \\
\hline Perempuan & 70 & 92.11 \\
\hline Laki-Laki & 6 & 7,89 \\
\hline $\begin{array}{lll}\mathbf{U} & \mathbf{m} & \mathbf{u}\end{array}$ & $\mathbf{r}$ & \\
\hline 19 & 3 & 3.95 \\
\hline 20 & 38 & 50.00 \\
\hline 21 & 32 & 42.11 \\
\hline 22 & 2 & 2.63 \\
\hline 24 & 1 & 1.32 \\
\hline
\end{tabular}

Berdasarkan Tabel 1 dapat diketahui bahwa jumlah responden dalam penelitian ini adalah 76 mahasiswa, terdiri dari 41 mahasiswa gizi dan 35 mahasiswa non gizi.
Berdasarkan jenis kelamin, responden lebih banyak mahasiswa perempuan dibandingkan dengan laki-laki. Umur rata-rata responden yaitu sekitar 20 dan 21 tahun. 


\section{B. Pengetahuan Sayur dan Buah}

Tabel 2. Pengetahuan Sayur Buah Mahasiswa gizi dan Non-gizi Poltekkes Kemenkes Tasikmalaya

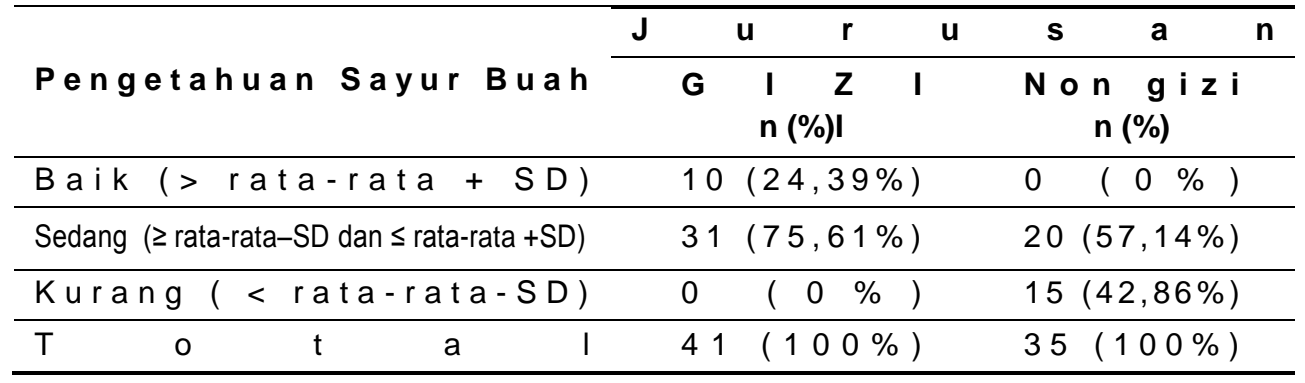

Hasil penelitian ini menunjukkan bahwa pengetahuan sayur dan buah mahasiswa gizi sebagian besar tergolong kategori sedang $(75,61 \%)$. Skor pengetahuan sayur dan buah mahasiswa non gizi juga sebagian besar tergolong kategori sedang (57,14\%). Apabila dibandingkan diantara keduanya mahasiswa gizi memiliki pengetahuan sayur dan buah yang lebih baik dibandingkan dengan mahasiswa non gizi. Mahasiswa gizi selama masa pendidikan sudah pernah terpapar pengetahuan di bidang gizi, termasuk tentang pentingnya konsumsi sayur dan buah.

Pertanyaan yang banyak dijawab salah oleh mahasiswa gizi yaitu mengenai kandungan serat larut dan tidak larut yang terkandung dalam sayuran dan buah-buahan, porsi buah minimal yang harus dimakan setiap hari, serta rerata nasional perilaku konsumsi sayur dan buah pada penduduk umur $>10$ tahun. Hal ini diduga karena mahasiswa kurang banyak membaca mengenai data dan pengetahuan mengenai kandungan gizi maupun porsi sayur dan buah yang dianjurkan. Berdasarkan hasil wawancara pada beberapa mahasiswa gizi, mahasiswa banyak yang lupa dengan pengetahuan tersebut.
Pertanyaan yang banyak dijawab salah oleh mahasiswa non gizi, yaitu mengenai porsi buah minimal yang harus dimakan setiap hari dan rerata nasional perilaku konsumsi sayur dan buah pada penduduk umur $>10$ tahun. Selain itu juga banyak yang tidak mengetahui tentang kandungan jenis antioksidan yang terdapat pada sayuran. Rendahnya pengetahuan mengenai hal tersebut diduga terjadi karena mahasiswa non gizi kurang terpapar dengan materimateri berkaitan gizi. Meskipun dalam rumpun kesehatan, namun ranah pendalamannya berbeda sehingga kurang memahami pengetahuan tersebut.

Idealnya pengetahuan mengenai sayur dan buah ini dikenal oleh semua kalangan sebagai pedoman untuk hidup sehat, sehingga dapat diaplikasikan dalam asupan sehari-hari sesuai anjuran. Sosialisasi mengenai anjuran konsumsi sayur dan buah sudah ada sejak dahulu, mulai dari slogan empat sehat lima sempurna, kemudian pedoman umum gizi seimbang tahun 2003, serta pedoman gizi seimbang tahun 2014 . Pedoman-pedoman tersebut menjelaskan pentingnya konsumsi sayur buah baik tersirat maupun tersurat.

\section{Pengeluaran untuk Konsumsi Sayur dan Buah}

Tabel 3 memberikan gambaran bahwa rerata total pengeluaran pada mahasiswa gizi, lebih tinggi dibanding rerata pengeluaran mahasiswa non gizi. Menurut Badan Pusat Statistik pada tahun 2014, rerata pengeluaran per kapita per bulan penduduk Indonesia untuk makanan dan non makanan adalah sebesar Rp 776.032. Hal ini menunjukkan bahwa total pengeluaran pada mahasiswa gizi maupun mahsiswa non gizi lebih tinggi dibanding rerata total pengeluaran penduduk Indonesia.

Rerata pengeluaran responden sebulan untuk non makanan menggambarkan 
kebalikan dari gambaran total pengeluaran, yang mana mahasiswa non gizi memiliki pengeluaran untuk bukan makanan yang lebih tinggi dibandingkan mahasiswa gizi, begitu juga dengan pengeluaran per kapita per bulan penduduk indonesia sebesar $\mathrm{Rp}$ 387.682 (BPS, 2014).

Tabel 3. Rerata Pengeluaran untuk Makanan dan Non-Makanan (per bulan) Buah Mahasiwa Jurusan Gizi dan Non-Gizi Poltekes Kemenkes Tasikmalaya

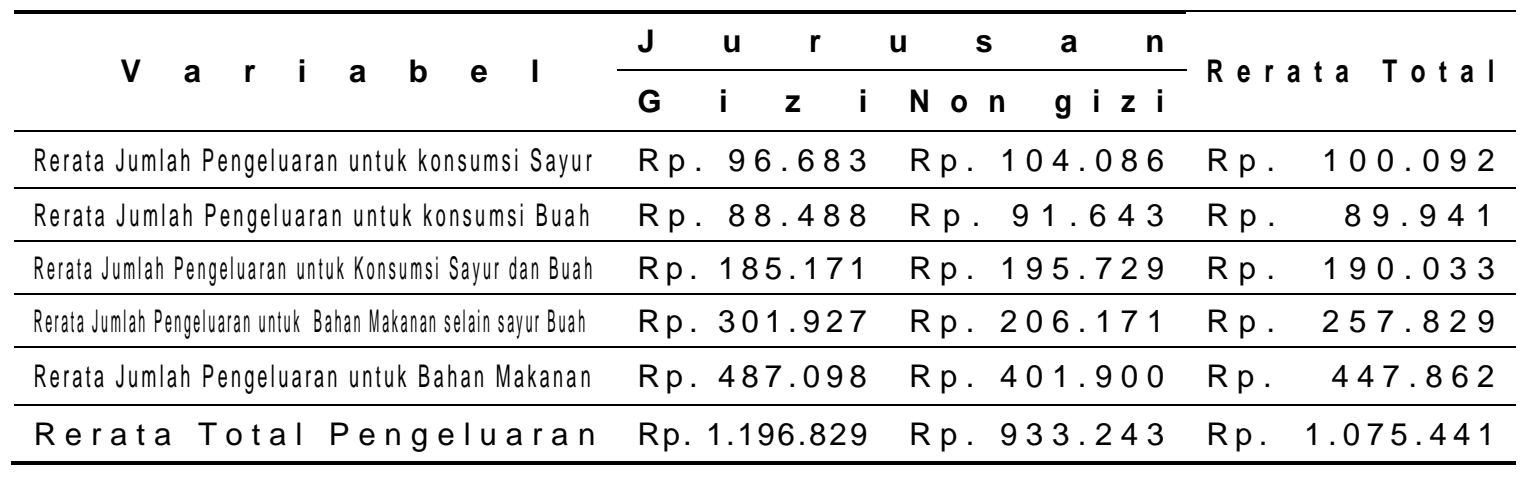

Pengeluaran responden sebulan per kapita per hari untuk bahan makanan menggambarkan bahwa rerata pengeluaran untuk bahan makanan mahasiswa gizi lebih tinggi daripada mahasiswa non gizi. Begitu juga jika dibandingkan dengan rerata penduduk Indonesia sebesar Rp 388.350 (BPS, 2014). Rerata Pengeluaran responden sebulan untuk bahan makanan selain sayur buah menggambarkan pengeluaran yang lebih rendah dari rerata pengeluaran penduduk Indonesia sebesar Rp 339.039. (BPS, 2014).

Namun pengeluaran mahasiswa gizi masih lebih tinggi dibanding mahasiswa non gizi. Data pengeluaran responden sebulan untuk sayur dan buah tersebut menunjukkan bahwa rerata pengeluaran pada mahasiswa non gizi lebih tinggi dari mahasiswa gizi, dan lebih tinggi 4 kali dibanding rerata pengeluaran untuk sayur buah penduduk Indonesia sebesar Rp 49.311 (BPS,2014). Rerata pengeluaran responden sebulan untuk sayur menunjukkan tingginya pengeluaran sebesar lebih 3 kali jika dibanding penduduk indonesia sebesar Rp 30.068,-. Sedangkan rerata pengeluaran responden sebulan untuk buah 4 kali lebih tinggi dibandingkan dengan penduduk Indonesia sebesar Rp 19.243 (BPS, 2014).

\section{Konsumsi Sayur dan Buah}

Tabel 4. Rerata Jumlah Konsumsi Sayur dan Buah Pada Mahasiswa gizi dan Non-gizi Poltekkes Kemenkes Tasikmalaya

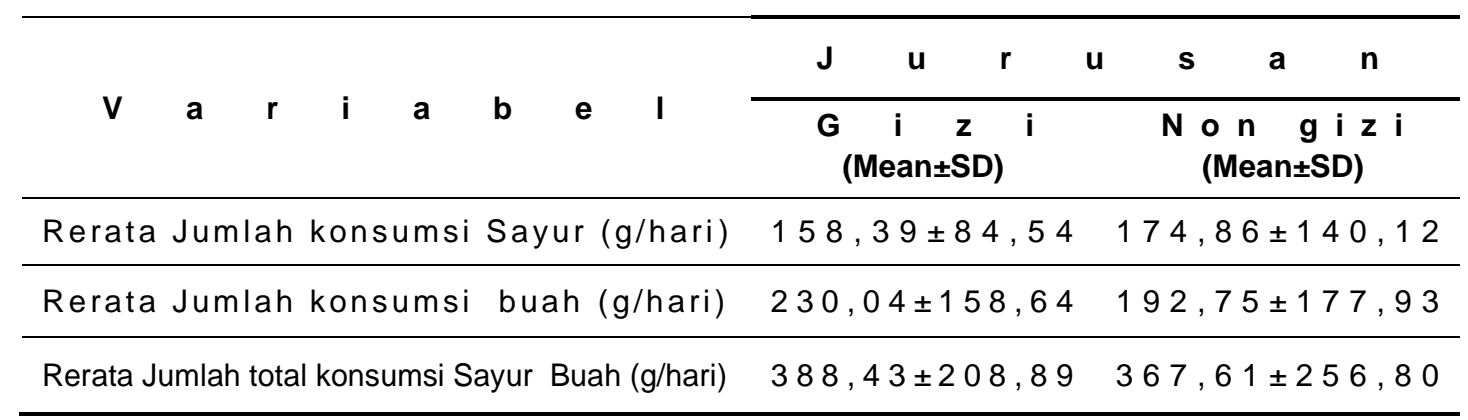


Hasil penelitian menunjukkan bahwa rerata jumlah konsumsi sayur mahasiswa non gizi lebih tinggi dibandingkan dengan mahasiswa gizi, sebaliknya rerata jumlah konsumsi buah lebih tinggi pada mahasiswa gizi daripada mahasiswa non gizi. Jika ditotal rerata jumlah konsumsi sayur buah mahasiswa gizi adalah $388,43 \mathrm{~g} / \mathrm{hari}$, sedangkan mahasiswa non gizi sebesar 367,61 g/hari (Tabel 4), Hal ini menunjukkan bahwa rerata jumlah konsumsi buah maupun sayur tersebut sudah berada di atas rerata konsumsi sayur buah dan olahannya pada penduduk Indonesia berdasarkan Studi Diet Total Survei Konsumsi Makanan Individu Indonesia tahun 2014, yaitu sebesar 33,5 g/orang/hari (Badan Litbangkes, 2014). Walaupun berada di atas rerata, namun masih rendah dari anjuran konsumsi sayuran dan buah-buahan menurut pedoman gizi seimbang (Kemenkes RI, 2014).

Tabel 5. Jumlah dan Frekuensi Konsumsi Sayur dan Buah Pada Mahasiswa gizi dan Non-gizi Poltekkes Kemenkes Tasikmalaya

\begin{tabular}{|c|c|c|c|}
\hline & $\mathbf{u}$ & $\mathbf{u}$ & a \\
\hline e I & $\begin{array}{lr}\text { i } & \text { z } \\
\text { n } & (\%)\end{array}$ & No & $\mathbf{n}_{\mathbf{n}(\%)}^{\mathbf{g}} \mathbf{i} \quad \mathbf{z} \mathbf{i}$ \\
\hline \multicolumn{4}{|l|}{ Jumlah Konsumsi Sayur } \\
\hline$\geq 250 \quad \mathrm{~g} / \mathrm{h}$ a $\mathrm{r}$ i & $5 \quad(12,20 \%)$ & \multicolumn{2}{|c|}{$8(22,86 \%)$} \\
\hline $\mathrm{g} / \mathrm{h}$ a $\mathrm{r}$ i & $36(87,80 \%)$ & & $27(77,14 \%)$ \\
\hline $\begin{array}{ccccc}\mathrm{T} & \mathrm{o} & \mathrm{t} & \mathrm{a} & \mathrm{l}\end{array}$ & 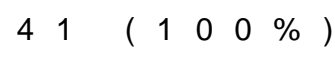 & & $35 \quad\left(\begin{array}{llll}1 & 0 & 0 & \%\end{array}\right)$ \\
\hline \multicolumn{4}{|l|}{ Frekuensi Konsumsi Sayur } \\
\hline$\geq 1 \quad \mathrm{k}$ a $\mathrm{l} \mathrm{i} / \mathrm{h}$ a $\mathrm{r}$ i & 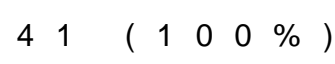 & & $23(65,71 \%)$ \\
\hline $1 \mathrm{k}$ a $\mathrm{li} / \mathrm{h}$ a $\mathrm{ri}$ & $0 \quad(0 \%)$ & & $12(34,29 \%)$ \\
\hline $\begin{array}{ccccc}\mathrm{T} & \mathrm{o} & \mathrm{t} & \mathrm{a} & \mathrm{l}\end{array}$ & $41 \quad\left(\begin{array}{llll}1 & 0 & 0 & \%\end{array}\right)$ & & $35 \quad\left(\begin{array}{llll}1 & 0 & 0 & \%\end{array}\right)$ \\
\hline \multicolumn{4}{|l|}{ Jumlah Konsumsi buah } \\
\hline$\geq 150 \quad \mathrm{~g} / \mathrm{h}$ a $\mathrm{r}$ i & $26(63,41 \%)$ & 15 & $(42,86 \%)$ \\
\hline $150 \quad \mathrm{~g} / \mathrm{h}$ a $\mathrm{r}$ i & $15(36,59 \%)$ & & $20(57,14 \%)$ \\
\hline $\begin{array}{lllll}\mathrm{T} & \mathrm{o} & \mathrm{t} & \mathrm{a} & \mathrm{l}\end{array}$ & 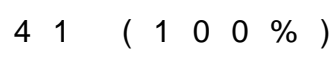 & \multicolumn{2}{|c|}{$35 \quad\left(\begin{array}{llll}1 & 0 & 0 & \%\end{array}\right)$} \\
\hline \multicolumn{4}{|l|}{ Frekuensi Konsumsi buah } \\
\hline$\geq 1 \quad \mathrm{k}$ a $\mathrm{l}$ i $/ \mathrm{h}$ a $\mathrm{r}$ i & $34(82,93 \%)$ & 13 & $(37,14 \%)$ \\
\hline$<1 \mathrm{ka} \mathrm{l} \mathrm{i} \mathrm{/} \mathrm{har} \mathrm{i}$ & $7 \quad(17,07 \%)$ & \multicolumn{2}{|c|}{$22(62,86 \%)$} \\
\hline $\begin{array}{ccccc}\mathrm{T} & \mathrm{o} & \mathrm{t} & \mathrm{a} & \mathrm{l}\end{array}$ & 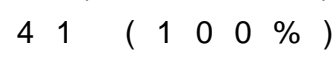 & \multicolumn{2}{|c|}{$35 \quad\left(\begin{array}{llll}1 & 0 & 0 & \%\end{array}\right)$} \\
\hline \multicolumn{4}{|l|}{ Jumlah Total Konsumsi Sayur dan Buah } \\
\hline$\geq 400 \mathrm{~g} / \mathrm{h}$ a $\mathrm{r}$ i & $19(46,34 \%)$ & 12 & $(34,29 \%)$ \\
\hline $\mathrm{g} / \mathrm{h}$ a $\mathrm{r} \mathrm{i}$ & $22(53,66 \%)$ & & $(65,71 \%)$ \\
\hline $\begin{array}{llll}0 & \mathrm{t} & \mathrm{a} & \mathrm{l}\end{array}$ & 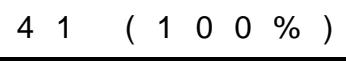 & & $35\left(\begin{array}{llll}1 & 0 & 0 & \%\end{array}\right)$ \\
\hline
\end{tabular}

Perubahan pola konsumsi pangan di Indonesia telah rnenyebabkan berkurangnya konsumsi sayuran dan buah-buahan hampir di semua propinsi di Indonesia (Muchtadi, 2001). Hasil penelitian ini menunjukkan bahwa jumlah sayur yang dikonsumsi oleh mahasiswa ini belum sesuai anjuran (kurang dari $250 \mathrm{~g}$ /hari), yaitu berturut-turut sebesar $87,80 \%$ dan $77,14 \%$ begitu juga dengan jumlah total konsumsi sayur dan buah (Tabel
5). Anjuran Pedoman Gizi Seimbang tahun 2014 yaitu $250 \mathrm{~g}$ sama dengan 2,5 porsi setiap hari, yaitu setara 2,5 gelas sayur setelah dimasak dan ditiriskan (Kemenkes, 2014). Hal ini didukung data laporan Riskesdas tahun 2007 dan 2013 yang menunjukkan masih tingginya proporsi rerata nasional perilaku konsumsi kurang sayur dan atau buah (Depkes, 2007 : Kemenkes, 2013). Hal berbeda ditunjukkan pada jumlah 
konsumsi buah pada mahasiswa gizi, sebanyak $63,41 \%$ sudah sesuai anjuran menurut Pedoman Gizi Seimbang tahun 2014 yaitu $150 \mathrm{~g}$ setiap hari sama dengan 1,5 porsi. yaitu setara dengan 3 buah pisang ambon ukuran sedang atau 1,5 potong pepaya ukuran sedang atau 3 buah jeruk ukuran sedang (Kemenkes RI, 2014).

Ada kecenderungan lebih tingginya presentase yang mengkonsumsi sesuai anjuran pada mahasiswa gizi daripada mahasiswa non gizi dari segi jumlah konsumsi sayur, buah maupun sayur buah (Tabel 5). Semua mahasiswa gizi (100\%) sudah mengkonsumsi sayur setiap harinya sesuai anjuran, sedangkan mahasiswa non gizi derajat keseringan (frekuensi) dalam hal mengkonsumsi sayur masih lebih rendah daripada mahasiswa gizi, hanya $65,71 \%$ saja yang dengan frekuensi konsumsi lebih dari sekali dalam seharinya. Begitu juga dengan frekuensi konsumsi buah-buahannya.

Perbedaan kebiasaan mengonsumsi buah dan sayur baik dari segi jumlah maupun jenis dapat dipengaruhi oleh beberapa faktor, diantaranya faktor lingkungan seperti ketersediaan buah dan sayur pada tingkat rumah tangga, faktor preferensi pribadi, pengetahuan tentang gizi, dan lingkungan sekolah juga menyediakan kesempatan untuk membentuk kebiasaan makan sejak anakanak termasuk kebiasaan mengonsumsi buah dan sayur (Kristjandottir et al. 2006).

Sejak lama sayuran dikategorikan sebagai bahan pangan sumber vitamin. Selain itu, sayuran juga mengandung komponen lain yang juga menyehatkan tubuh, yaitu antioksidan dan serat pangan (Muchtadi, 2001). Beberapa penelitian menemukan bahwa mengonsumsi buah dan sayur dapat mengurangi timbulnya penyakit, seperti kanker dan jantung, terutama buah yang berwarna merah atau kuning, seperti wortel, tomat, aprikot, bit, dan lain-lain. Buah dan sayur juga dapat bermanfaat untuk menghentikan tumbuhnya bakteri, melindungi dari infeksi, menjaga pertahanan tubuh, menurunkan kadar gula darah, dan mencegah kolesterol di dalam tubuh (Jusup, 2007). Beberapa dampak apabila seseorang kurang konsumsi buah dan sayur menurut Ruwaidah (2007), antara lain meningkatkan kolesterol darah, gangguan penglihatan/mata, menurunkan kekebalan tubuh, meningkatkan risiko kegemukan, risiko kanker kolon, dan risiko konstipasi.

Sayuran merupakan menu yang hampir selalu terdapat dalam hidangan sehari-hari masyarakat Indonesia, dalam keadaan mentah (sebagai lalapan segar) atau setelah diolah menjadi berbagai macam bentuk masakan (Muchtadi, 2001). Hasil penelitian menunjukkan bahwa jenis konsumsi sayur mahasiswa gizi paling banyak adalah wortel, bayam dan ketimun, sedangkan pada mahasiswa non gizi adalah ketimun, wortel dan kangkung (Gambar 1). Jenis konsumsi sayur pada mahasiswa belum memenuhi anjuran pedoman gizi seimbang dalam hal keanekaragamannya. Padahal jenis sayuran yang ditemukan di pasar-pasar jauh lebih banyak di daerah tropis seperti di Indonesia daripada di negara-negara beriklim sedang (Wiliams et al., 1993).

Menurut Tarwotjo (1998) buah-buahan dalam dunia kuliner sering disebut dengan istilah makanan pencuci mulut yang dihidangkan sebagai makanan penutup atau hidangan terakhir dari suatu jamuan makan sehari-hari. Hal ini dimungkinkan karena buah-buahan dapat menetralkan rongga mulut setelah makan nasi dan berbagai macam lauk pauknya. Buah dapat dikonsumsi secara langsung atau dalam bentuk minuman seperti jus buah. Indonesia merupakan wilayah tropis yang kaya akan keanekaragaman hayati termasuk berbagai jenis buah-buahan.

Hasil penelitian menunjukkan keanekaragaman dari segi jumlah konsumsi buah baik pada mahasiswa gizi maupun non gizi belum memenuhi anjuran (Gambar 2). Konsumsi buah-buahan tergantung dari berbagai hal diantaranya ketersediaan akibat keterkaitannya dengan musim. Tanaman buah-buahan yang cocok tumbuh di daerah tropis seperti di Indonesia adalah alpukat, belimbing, duku, durian, duwet, kedongdong, mangga, manggis, nangka, nenas, pisang, rambutan dan srikaya (Ashari, 2009). 
Keanekaragaman jenis buah di Indonesia akan menyebabkan musim buah yang berbeda, dengan demikian akan selalu dijumpai aneka buah-buahan sepanjang tahun. Indonesia mengalami 2 pergantian musim, sebagia akibatnya adanya buah seasonal (musiman) dan non-seasonal (tidak tergantung musim). Contohnya seperti durian, rambutan dan duku adalah buah-buahan yang dipengaruhi oleh musim, sedangkan papaya, belimbing dan pisang adalah jenis buah-buahan yang tidak dipengaruhi oleh musim, jadi ketersediaannya selalu ada sepanjang tahun (Sujarno, 2008).

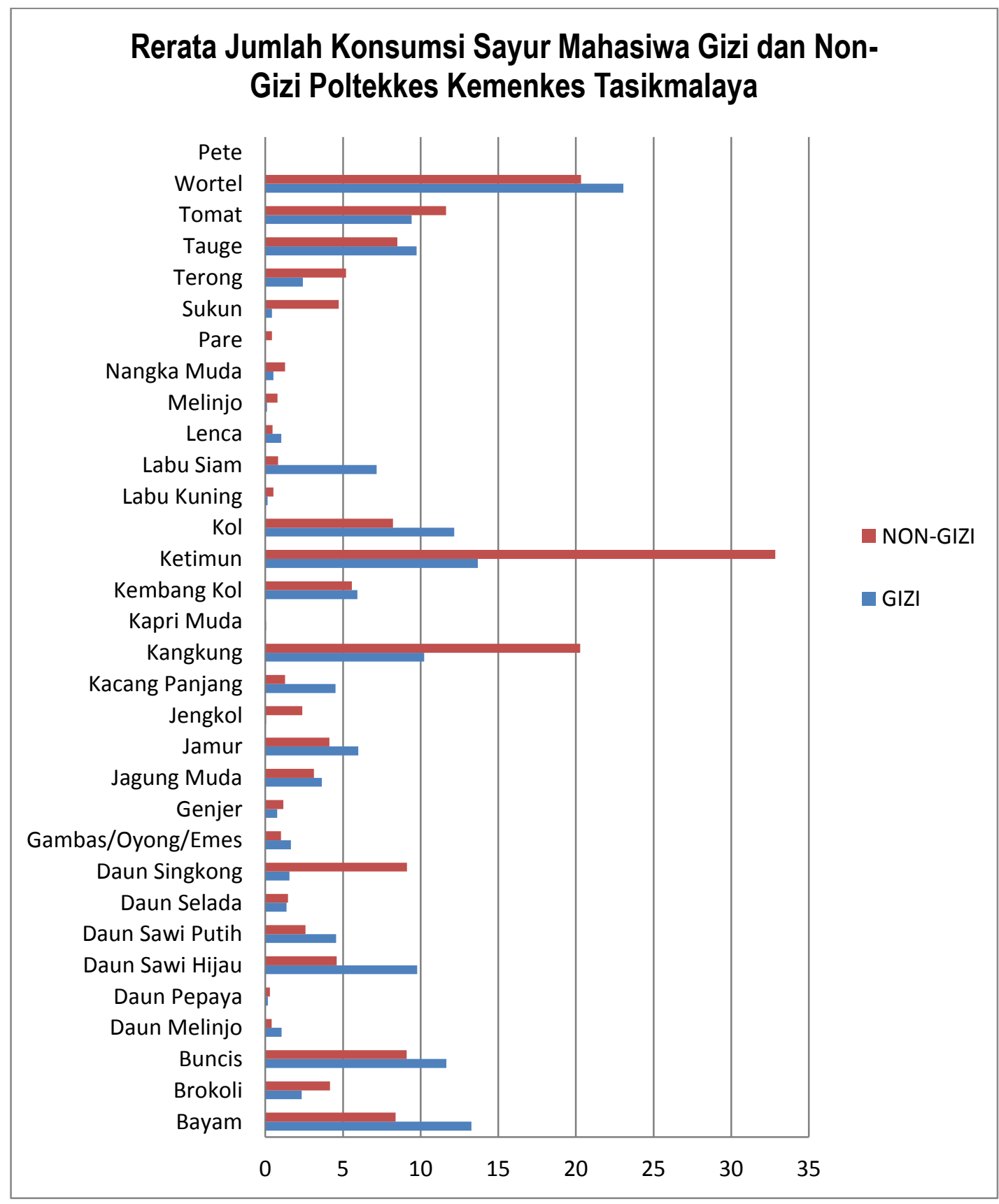

Gambar 1. Rerata Jumlah Konsumsi Sayur Mahasiswa gizi dan Non gizi Poltekkes Kemenkes Tasikmalaya 


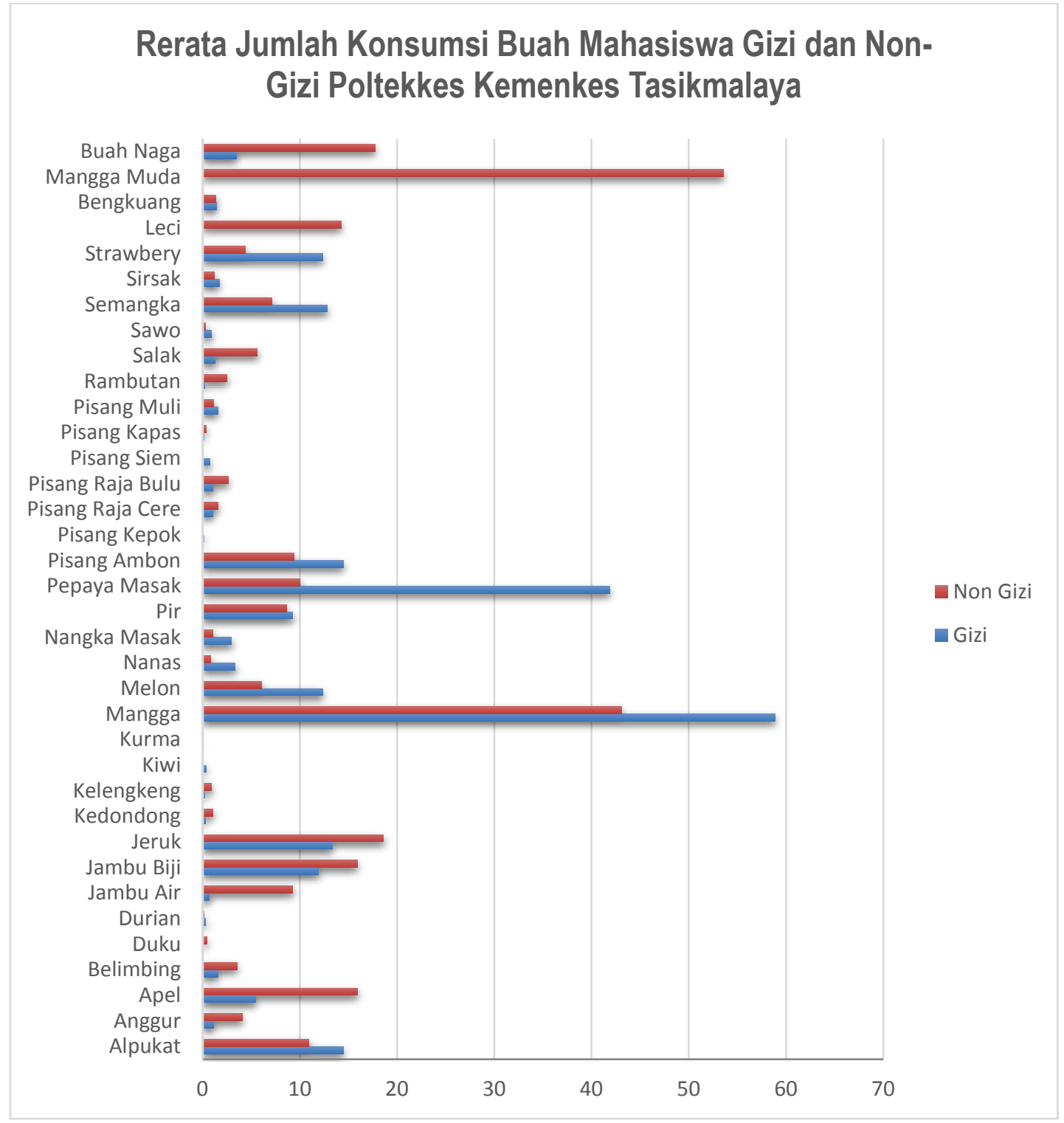

Gambar 2. Rerata Jumlah Konsumsi Sayur Mahasiswa gizi dan Non gizi Poltekkes Kemenkes Tasikmalaya

Hasil penelitian menunjukkan bahwa rerata jumlah konsumsi buah menurut jenisnya, 3 yang terbanyak pada Mahasiswa gizi adalah mangga, pepaya masak dan pisang ambon, sedangkan pada Mahasiswa non gizi adalah mangga muda, mangga dan jeruk (Gambar 2). Selain karena ketersediaannya terkait musim, seperti pada konsumsi jenis buah mangga pada mahasiswa gizi maupun non gizi memiliki jumlah terbanyak diantara jenis buah lainnya, dikarenakan pada saat jalannya penelitian buah mangga sedang musim yang banyak terdapat di pasar-pasar daerah Tasikmalaya, atau Jawa Barat (lokal). Ketersediaan barang maupun dari segi keterjangkauan harga ini merupakan jaminan seseorang dapat mengkonsumsi buah-buahan jenis tersebut. Menurut Dinas pertanian Jawa Barat (2013), Tasikmalaya memiliki komoditas unggulan daerah dalam produksi buah yaitu duku, durian, manggis, pisang, salak, dan sirsak. Sedangkan tomat adalah komoditas unggulan Jawa Barat dari wilayah Bandung, Garut dan Cianjur.

\section{KESIMPULAN}


Kesimpulan penelitian ini adalah sebagian besar pengetahuan tentang sayur buah mahasiswa gizi dan non-gizi tergolong kategori sedang. Pengetahuan, rerata jumlah total konsumsi serta rerata pengeluaran sayur dan buah mahasiswa gizi lebih baik daripada mahasiswa non gizi. Beberapa diantaranya masih belum sesuai anjuran dari segi jumlah

\section{REFERENSI}

Ashari, S. .2009. Meningkatkan Keunggulan Bebuahan Tropis Indonesia, Yogyakarta: Penerbit ANDI.

Badan Pusat Statistik. 2015. Pengeluaran rumah tangga. www.bps.go.id.

Badan Litbangkes.2014. Survei Konsumsi Makanan Individu dalam Studi Diet Total 2014. Jakarta : Kemenkes RI

Bapenas. 2011. Rencana Aksi Nasional Pangan dan Gizi 2011-2015. Jakarta: Bapenas.

Depkes RI. 2007, RumahTanggaSehatDenganPerilakuHid updanSehat,JakartaPusatPromkesDepk es RI

Depkes.2008. Riset Kesehatan Dasar (Riskesdas 2007). Badan Penelitian dan Pengembangan Depkes RI. Jakarta

Dinas Pertanian Kota Tasikmalaya. 2014. Sayuran dan Buah-Buahan Unggulan Kota Tasikmalaya

Kemenkes RI. 2013. Riset Kesehatan Dasar (Riskesdas 2013). Badan Penelitian dan Pengembangan Kemenkes RI. Jakarta

Kemenkes RI. 2014. Pedoman Gizi Seimbang. Direktorat Jenderal Bina Gizi dan KIA. Jakarta. maupun frekuensinya. Saran dari hasil penelitian ini adalah perlunya peningkatan kesadaran dari mahasiswa kesehatan akan pentingnya manfaat sayur dan buah serta peningkatan pengetahuan dan mengaplikasikan jumlah dan frekuensi yang dikonsumsi sesuai anjuran Pedoman Gizi Seimbang.

Kristjansdottir et al. 2006. Determinants of Fruit and Vegetable Intake among 11Year-Old.

Muchtadi, D..2001. Sayuran sebagai Sumber Serat Pangan untuk Mencegah Timbulnya Penyakit Degeneratif. Jurnal Teknologi dan Industri Pangan, XII(1), pp.61-71.

Jusup L. 2007. Sehat dan Bugar Dengan Jus Buah dan Sayuran Tropis. Jakarta: PT Gramedia Pustaka Utama

Ruwaidah, Amin .2007. Penyakit akibat lalai mengkonsumsi buah dan sayur serta solusi penyembuhannya. Diakses pada tanggal 15 April 2010 dari www.healindonesia.com.

Tarwotjo, C.S..1998. Dasar-Dasar Gizi Kuliner, Jakarta: PT Gramedia Widiasarana Indonesia.

Williams, C.N., Uzo, J.O. dan Peregrine, W.T.H., 1993. Produksi Sayuran di Daerah Tropika G. Tjitrosoepomo, ed., Yogyakarta: Gadjah Mada University Press. 